\title{
Retrospective Experiential Learning Theory and its Impact on Countering Social Exclusion in Ecotourism
}

\author{
Mathew C. D. ${ }^{1} \&$ P. S. Aithal ${ }^{2}$ \\ ${ }^{1}$ Post Doctorate Fellow, Srinivas University, Mangalore, India \& Adjunct Faculty in \\ Management Studies, IIIT, Kottayam, India \\ OrcidID: 0000-0001-8102-2823; E-mail: brincepmathew@gmail.com \\ ${ }^{2}$ Professor, College of Management and Commerce, Srinivas University, Mangalore, India \\ OrcidID: 0000-0002-4691-8736; E-mail: psaithal@gmail.com
}

Area/Section: Management

Type of the Paper: Research Paper.

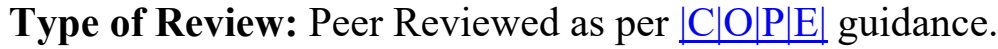

Indexed in: OpenAIRE.

DOI: http://doi.org/10.5281/zenodo.3660956.

Google Scholar Citation: IJMTS.

\section{How to Cite this Paper:}

Mathew C. D., \& Aithal P. S. (2020). Retrospective Experiential Learning Theory and its Impact on Countering Social Exclusion in Ecotourism. International Journal of Management, Technology, and Social Sciences (IJMTS), 5(1), 18-23.

DOI: http://doi.org/10.5281/zenodo.3660956.

International Journal of Management, Technology, and Social Sciences (IJMTS)

A Refereed International Journal of Srinivas University, India.

(C) With Authors.

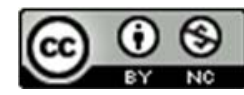

This work is licensed under a Creative Commons Attribution-Non-Commercial 4.0 International License subject to proper citation to the publication source of the work.

Disclaimer: The scholarly papers as reviewed and published by the Srinivas Publications (S.P.), India are the views and opinions of their respective authors and are not the views or opinions of the SP. The SP disclaims of any harm or loss caused due to the published content to any party. 


\title{
Retrospective Experiential Learning Theory and its Impact on Countering Social Exclusion in Ecotourism
}

\author{
Mathew C. D. ${ }^{1} \&$ P. S. Aithal ${ }^{2}$ \\ ${ }^{1}$ Post Doctorate Fellow, Srinivas University, Mangalore, India \& Adjunct Faculty in \\ Management Studies, IIIT, Kottayam, India \\ OrcidID: 0000-0001-8102-2823; E-mail: brincepmathew@gmail.com \\ ${ }^{2}$ Professor, College of Management and Commerce, Srinivas University, Mangalore, India \\ OrcidID: 0000-0002-4691-8736; E-mail: psaithal@gmail.com
}

\begin{abstract}
Retrospective Experiential Learning (REL) is an instrument for regularising and normalising the guiding experience of the guides. Ultimately it results in routinising the very rare excellent service that happened earlier. In this paper, the Retrospective Experiential Learning test is carried out at Thenmala and PTR concerning Client Associations Management. Guides have been asked to reminisce their good experiences in connection with tourism services. REL has contributed towards enhanced service quality. The empirical study shows that REL can produce results. It has been found that concentrated REL strategy is not applicable to the two destinations. Here, the tourists who are assessed in connection with implementing new ideas told that they would prefer intuitive, imaginative, creative, participative, and idea generating environment to enjoy ecotourism with local tourist guides rather than a rigid bureaucratic environment. The paper focuses on the impact of REL on service quality in ecotourism sector. The discussions are directed towards improving service quality and its impact on social exclusion.
\end{abstract}

Keywords: REL, Customer satisfaction, Service quality, Local guides, PTR, Thenmala.

\section{INTRODUCTION :}

According to psychological terms, any relatively permanent change in behaviour based on experience is called learning. Retrospective Experiential Learning (REL) is an instrument for regularising and normalising the guiding experience of the guides. Ultimately it results in routinising the very rare excellent service that happened earlier. Through REL one can produce the best previous experience on a regular basis. In this test, the researcher reproduced the best guiding experience of the guides. The paper in the Journal of Workplace Learning by Olsson, Bjoorn \& Jonson, 2008) [1], speaks on retrospective learning about insensible, budding wisdom amongst workers of an establishment and proposes in what way to understand these instants of empirical wisdom for organisational wisdom. This published research work put on the applied study, converging on the empirical wisdom coming through routine activities in the experimental establishment at Volvo Car's manufacture unit based in Sweden. The research proposes that the capability development that happened earlier should develop an essential portion of upcoming instructive procedures. This research is an advancement of the abovementioned one, as the quoted one focuses on actual structural instruction procedures. In the meanwhile, the investigator steered this test for enhancing structural efficiency by focussing on the three-way extremity lines- better client satisfaction, greater financial welfares for workforces and ability enrichment for workforces on customary base. As per the Ecotourism Directorate of Kerala State of India, there are 56 ecotourism destinations in the State. Even though there are 56 destinations, only PTR (Periyar Tiger Reserve) and Thenmala have been developed to 
the full potential. Thenmala is known as the one and only planned ecotourism destination of Kerala and PTR is the one that is having the endangered species Tigers. As these two destinations have been fully developed, these two tourist places are considered for our REL study.

\section{SURVEY OF LITERATURE :}

In a journal article by Beerli \& Martin, 2004 [2], a considerable dimension of research has been enclosed concerning the issues impelling a destination's brand equity. Nevertheless, some proportions concerning service excellence have been enclosed, the paper which was available in Annals of Tourism does not stretch a detailed examination in connection with visitor dealings managing. Here the investigator distillates on refining visitor dealings managing through performance reform. The research paper published by Chowdhary \& Prakash, in 2008 [3], portrays a respectable proportional reading amongst outing attendant training and additional packages in connection with approach and method. In this research, the investigator focuses on necessity based traveller guide training and its progressive influences.

Seven Strategies for Change' has been suggested for change agents (Kotter \& Schlesinger, 1979) [4]. The said article in Harvard Business Review is concerned about choosing a strategy for change. Here the researcher has applied Survey Feedback in addition to the seven strategies.

In another paper published in Personnel Psychology (Fedor, D. B. et al. 2006) [5] pronounces around forming a constructive viewpoint from the part of workers throughout the transformation procedure. Now in this investigational research, emphasis has been agreed on collaborative management during the REL procedure. Empowerment of service workers have been covered in detail (Bowen, D. E. et al, 1992) [6] and it says about legendary stories of employees who recovered failed business transactions. Here, the researcher has applied Survey Feedback to understand the reasons for ineffective service recovery. Another article in American Sociological Review [6] on the empowerment of service workers emphasize on the approach of frontline interaction personnel where the researcher had taken the steps at the supervisor level.

\section{AIM OF THE TEST :}

(1) To understand the relationship between REL and tourist grievances (Mathew Renganathan \& Joseph, 2012) [7].

\section{Hypothesis of the Test :}

(1) There is no relationship between REL and tourist complaints.

\section{Rationality in Selecting Local Tourist Guides as the Focus Group of REL Testing :}

In the said destinations local people act as tourist guides. REL is an employee centric and employee focussed competence development instrument. Hence the concentration group (tribal tourist guides) have been nominated for the REL assessment procedure.

Table 1 : Analysis on Customer Complaints at Thenmala

\begin{tabular}{|c|c|c|}
\hline \multicolumn{3}{|c|}{$\begin{array}{l}\text { Fraction of Tourist Grievances at } \\
\text { Thenmala }\end{array}$} \\
\hline $\begin{array}{l}\text { Monitoring } \\
\text { period }\end{array}$ & Prior to REL & After REL \\
\hline Oct-Dec 2018 & 2.6 & - \\
\hline Jan-Mar 2019 & 2.7 & - \\
\hline Apr-June 2019 & 2.5 & - \\
\hline Jul-Sept 2019 & - & 0.4 \\
\hline
\end{tabular}

Table 2 : Analysis on Customer Complaints at PTR

\begin{tabular}{|l|l|l|}
\hline \multicolumn{3}{|l|}{ Fraction of Tourist Grievances at PTR } \\
\hline $\begin{array}{l}\text { Monitoring } \\
\text { period }\end{array}$ & Prior to REL & After REL \\
\hline Oct-Dec 2018 & 2.6 & - \\
\hline Jan-Mar 2019 & 2.9 & - \\
\hline Apr-June 2019 & 2.8 & - \\
\hline Jul-Sept 2019 & - & 0.4 \\
\hline
\end{tabular}

It has been established that together in PTR and in Thenmala afterwards the experimentation of Retrospective Experiential Learning, ratios of client criticisms have reduced below one percentage. It displays that REL is able to yield positive outcomes.

Concentrated Vs Differentiated Strategy for REL : 
Through Human Resource Committees at PTR and Thenmala, the researcher sought the possibility of exploring a concentrated strategy for implementing REL at PTR and Thenmala on an eight-dimensional scale of ten points each. The dimensions and their meanings are given below.

1. Tourism Performance- primary tourism product characteristics like the nature of ecotourism activities.

2. Features- additional benefits to the tourists

3. Conformance-meeting eco-tourism industry standards

4. Service- redressing customer complaints

5. Response- interpersonal behaviour

6. Aesthetics- manifestation of eco-tourism products

7.Brand Equity- impression about the destination or its ranking

8. Customer Satisfaction- Keeping the tourist in delights and makes him loyal.

REL characteristics were tested by 16 tourist members from Thenmala and PTR on the said set of scale items and the scale is ordinal. The hypothesis, that there is no difference in REL Characteristics in two destinations has been tested at 5\% level of significance by Wilcoxon matched- pairs signed rank test. tourist members at PTR and Thenmala have been brought together on a common platform. The researcher has given them room to discuss REL characteristics as regards with both the destinations. Each member rated REL characteristics in both the destinations based on his own perceptions. The researcher had taken down the minutes of the lively discussions. The findings of the discussions are elaborated under eight different themes but possibly overlapping ones. ANOVA test has been done at the end of the brainstorming sessions.

Table 3 : Scores of REL Characteristics

\begin{tabular}{|c|c|c|}
\hline \multirow{2}{*}{$\begin{array}{c}\text { S. No. of } \\
\text { Tourist } \\
\text { Members }\end{array}$} & \multicolumn{2}{|c|}{ Destinations } \\
\cline { 2 - 3 } & Thenmala & PTR \\
\hline 1 & 73 & 51 \\
\hline 2 & 43 & 41 \\
\hline 3 & 47 & 43 \\
\hline 4 & 53 & 41 \\
\hline
\end{tabular}

\begin{tabular}{|c|c|c|}
\hline 5 & 58 & 47 \\
\hline 6 & 47 & 32 \\
\hline 7 & 52 & 24 \\
\hline 8 & 58 & 58 \\
\hline 9 & 38 & 43 \\
\hline 10 & 61 & 53 \\
\hline 11 & 56 & 52 \\
\hline 12 & 56 & 57 \\
\hline 13 & 34 & 44 \\
\hline 14 & 55 & 57 \\
\hline 15 & 65 & 40 \\
\hline 16 & 75 & 68 \\
\hline
\end{tabular}

The researcher composed the following hypothesis :

Null Hypothesis: There is not any change amongst the perceived REL elements of two destinations.

Alternate Hypothesis: There is a change amongst the perceived REL elements of two destinations.

Analytical Results: After dropping the pair number 8 (difference is zero), there are only 15 observations. As the test is two-tailed, the tabled value at five percentage level of risk is 25 , while the calculated value is 18.5 . As the calculated value is not as much of the tabled value, the null hypothesis does not stand and we conclude that there is variance amongst the perceived REL elements of the two destinations. Therefore, it can be concluded that concentrated REL strategy is not applicable for the two destinations.

\section{ANOVA TEST- TO TEST THE LIKELIHOOD OF SOCIAL ACCEPTANCE FROM TOURISTS :}

The researcher wanted to know whether there is any significant difference as regards with accepting tourist guides between the tourists from different places after implementing REL. Because during the discussions domestic tourists showed greater resistance than their foreign counter parts. Tourists were assessed on a fivedimensional scale (each dimension is having ten points) on weekly basis for a period of four consecutive weeks. The researcher assessed tourists from different levels based on openness to new communication, sharing new thoughts, 
encouraging new thoughts, accepting new thoughts and implementing new thoughts.

Table 4: Weekly Likelihood of Social Acceptance from Tourists

\begin{tabular}{|l|l|l|l|}
\hline & \multicolumn{3}{|c|}{ Different Supervisory Levels } \\
\hline Week & Local & National & Foreign \\
\hline First & 30 & 25 & 25 \\
Second & 35 & 25 & 20 \\
Third & 15 & 15 & 15 \\
Fourth & 40 & 35 & 20 \\
\hline
\end{tabular}

The researcher composed the following hypotheses :

Null Hypothesis: There is no relationship between tourists from different locations and likelihood of social acceptance.

Alternate Hypothesis: There is relationship between tourists from different locations and likelihood of social acceptance.

\section{Analytical Results :}

The calculated $\mathrm{F}$ value is less than the critical $\mathrm{F}$ value $(1.50<4.26)$. Thus, we accept the null hypothesis that there is no difference in tourists from different locations as regards to social acceptance. During the discussions, the local guides showed resistance because of their inability to comprehend new ideas, not because of the fact that it is not amenable to them. After all, tourists are not resistant to implementing new ideas, provided things are clear to them. Organization specialists in normal circumstances habitually accept that by means of insight to mark conclusions is illogical or futile (Agor,1986) [8]. Here the tourists who are assessed in connection with implementing new ideas told that they would prefer intuitive, imaginative, creative, participative and idea generating environments to enjoy eco-tourism with local tourist guides rather than a rigid bureaucratic environment. Parallel learning structures are devices of introducing and managing change in large bureaucratic organisations (Bushe \& Shani, 1991) [9].

Table 5: Analysis of Variance Table for One-factor ANOVA Test

\begin{tabular}{|l|l|l|l|l|l|}
\hline $\begin{array}{l}\text { Source of } \\
\text { variation }\end{array}$ & $\begin{array}{l}\text { Sum of } \\
\text { Square } \\
\text { (SS) }\end{array}$ & $\begin{array}{l}\text { Degrees of } \\
\text { freedom } \\
\text { (d.f) }\end{array}$ & $\begin{array}{l}\text { Mean } \\
\text { Square } \\
\text { (MS)-SS/d.f }\end{array}$ & F-ratio & F-critical value \\
\hline $\begin{array}{l}\text { Between samples } \\
\text { Within samples }\end{array}$ & $\begin{array}{l}200 \\
\text { Total }\end{array}$ & 2 & 100 & $100 / 66.6$ & 4.26 (for 2,9 d.f) \\
\hline
\end{tabular}

\section{IMPLICATIONS OF THE RESEARCH HYPOTHESIS \& FUTURE SCOPE :}

Still, the stakeholders in the tourism industry struggle to segregate eco-tourism and ecofriendly tourism ("Eco Labelling", 2012) [10]. This contradiction will continue as long as tourism remains in the ambit of profit making and forgets that eco-tourism is nature based on the support of the local populace. Further research can be concentrated on applying REL to cater to the different needs of eco-tourists such as appreciating and conserving nature, acquiring knowledge on nature etc. It's a subtle and minute research area with the greater focus on differentiated needs of the tourists.

\section{CONCLUSION :}

One of the main methods to distinguish an ecotourism endpoint is to provide reliably great excellence facility than other kinds of tourism. The main factor is to come across or outdo the target travellers' service excellence outlooks. Consumer gratification is one of the central drives of an excellence organisation scheme (Cochran \& Craig, 2001) [11]. This brain storming session was aimed at improving the tourist satisfaction and the tourist guides' motivation levels. Client devotion can be continued only by upholding a positive assessment when equated with other players 
(Gardner, 2001) [12]. According to REL discussions tourist's expectations are formed by their past experiences, mouth publicity, and destination advertising through websites. The tourists choose destinations on these bases and, after receiving service, compare the perceived service with the expected service. The coming deliberations may be directed towards enlightening the service excellence. As the local tourist guides belong to local people, their social status needs to be improved. Therefore, ecotourism has to be promoted based on inclusive growth. Social upliftment of the tribal populace has to be given the paramount importance, as they are still the marginalised sector in terms of living standards. Local tourist guides are tribes. They belong to the marginalised category. Basically, it's an experimental design. Before after the same group undergoing intervention, resulting in social acceptance after the application of REL. Improved guiding and better economic benefits help them to be part of main stream and effectively counter social exclusion.

\section{REFERENCES :}

[1] Olsson, Annika, Bjoorn, Urban \& Jonson, Gunilla (2008). Experiential learning in retrospect: a future organisational challenge. Journal of Workplace Learning, 20(6), 431442.

[2] Beerli, A., \& Martin, J. D. (2004). Factors influencing destination image. Annals of tourism research, 31(3), 657-681.

[3] Chowdhary, N. \& Prakash, M. (2008). Tour guide training in India: a comparison of content and approach with other programmes. Working paper, Indian Institute of Tourism and Travel Management. India: Gwalior.

[4] Kotter J.P. \& Schlesinger L.A. (1979). Choosing strategies for change. Harvard Business Review, pp. 716-736.

[5] Fedor, D. B., Caldwell, S., \& Herold, D. M. (2006). The effects of organizational changes on employee commitment: A multilevel investigation. Personnel Psychology, 59(1), 1-29.
[6] Bowen, D. E., \& Lawler III, E. E. (1992). The empowerment of service workers: what, why, how and when. American Sociological Review, (31), 31-39.

[7] Mathew, Ranganathan, \& Joseph (2012). New Learning Theory and its Resultant Impact on Achieving Economic Objectives. Journal of Economics and Sustainable Development, 3(3), 32-48.

[8] Agor, W. H. (1986). The logic of intuition: How top executives make important decisions. Organizational Dynamics, 14(3), 5-18.

[9] Bushe G. R \& Shani A. B. (1991). Parallel learning structures. Reading, MA: AddisonWesley Publishing Company. Chapter.7, pp.125.

[10] Eco labelling (2012, August 6). The New Indian Express, p.2.

[11] Cochran, C. (2001). Customer satisfaction: the elusive quarry. Quality Digest, 21(11), 45-52.

[12] Gardner, Robert (2001). What Do Customers Value. Quality Progress, 41-48. 